\title{
An Approach to Performance Budgeting at the Florida Atlantic University Library
}

\begin{abstract}
The article summarizes the problems encountered at the FAU library in 1967 and the library's subsequent reorganization. A detailed cost study is analyzed and the Clapp-Jordan and University of Washington formulae for budgeting are described, as well as a modified formula. The resulting program performance budgeting system is now in use by the state university system of Florida.
\end{abstract}

\begin{abstract}
IN Fall, 1967, the author began the task of revitalizing and rebuilding the Florida Atlantic University library after the collapse of a much-heralded and publicized attempt to create the "only fully automated University Library in the world." The disappointment, frustration, disillusionment, anger, and bitterness which were part of the aftermath of failure infected everyone involved: the library staff, the staff of the computer center, the university administration, the office of the State Board of Regents, and the faculty and students of the university, who ultimately had to bear the real burdens of a library unable to function.

The Technical Services Division was the focal point of the effort to bring the computer into the library. It was the responsibility of this division to create the machine-readable data base which would support the management information system, create the necessary bibliographic records (including a computerbased book catalog), and make possible large scale programs in the area of in-
\end{abstract}

Dr. Axford is University Librarian at Arizona State University, Tempe, Arizona. formation retrieval, especially selective dissemination of information. Consequently, when the project failed, the Technical Services Division, for all practical purposes, ceased to function.

By spring, 1967, roughly three and one-half years after the library opened its doors, it was estimated that a majority of the titles held were either uncataloged or incompletely cataloged. Serial and acquisitions records were chaotic to the point of being useless, and there was an enormous backlog of unpaid bills, some of which dated back to 1963.

On the "other side" of the library, public services were functioning on a not much more than a building-open basis. The chaotic state of the public catalog, the journal collection, and the book shelves made reference services next to impossible. Everywhere there were reminders that the hopes which launched the experiment had become not an "awakening dream" but a nightmare. The library had disintegrated to the point where it was almost a liability rather than an asset with respect to the educational mission of the university. 
Crushing evidence as to its status within the academic community came in the summer of 1967, when the university administration withdrew over $\$ 250,000$ from the book budget. This action was taken on the premise that until the library could be reorganized, a large book budget would only result in even greater backlogs of unprocessed materials. ${ }^{1}$

In attacking the problem of rebuilding the library, several developments at the state level had to be given serious consideration. Foremost among these were the prevailing "no new taxes" mood of the state legislature and its demand that state agencies shift to a program budget by $1971 / 72$. Of equal importance was the generally unfavorable attitude toward the professional librarians which prevailed in both the legislature and the Board of Regents' office as a result of a state-wide personnel study.

In 1965, the consulting firm of Cresap, McCormick, and Paget (CMP) was hired by the legislature to survey all state positions not subject to the Florida merit system and to develop a uniform classification and pay scale. Within the state university system, 679 positions classified "Administrative and Professional" (A\&P) came under particularly close scrutiny. In approximately 160 of these positions the incumbents were professional librarians.

In its final report, CMP recommended that the composition of the A\&P group be "suitably refined and reconstructed" to include only those positions "which are primarily professional in character and academic in nature." Significantly, the consulting firm did not believe that the assigned responsibilities of the professional librarians in the university system met these criteria. It based this opinion on an analysis of the position questionnaires filled out by the librarians themselves which revealed a very high percentage of time spent on unquestionably clerical routines and tasks. $^{2}$
Although the Board of Regents' office eventually rejected the recommendation that librarians be classified as subprofessional personnel rather than in the A\&P group, this decision seemed based as much on a desire to keep peace in the family as out of any real conviction that CMP's findings were faulty or its recommendations without merit. As a matter of fact, it was clear from subsequent developments that the opposite was true. As the Board of Regents' office moved toward the development of an entirely new pay and classification plan which would retain A\&P status for librarians, it was made very clear that reaping the improvements in salaries and fringe benefits contained in the plan would be contingent both upon selective weeding to reduce the number of $A \& P$ positions in each library, and on convincing evidence that all persons appointed at this level would be assigned responsibilities which would be in fact "primarily professional in character and academic in orientation."

These directives made it obvious that lurking in the Board of Regents' office was a strong belief that CMP's finding regarding the level of performance by professional librarians in the university system was essentially correct. It later became equally clear that the new classification and pay schedule was specifically designed to provide incentives and trade-offs which would result in fewer, but, on the other hand, far better paid A\&P positions. ${ }^{3}$

Due to the failure to achieve the original goals of the library, the skepticism regarding the profession at the state level was probably more keenly felt at FAU than on any other campus in the system. Although the failure was by no means entirely the fault of the library, there existed in the Board of Regents' office a feeling that it somehow illustrated the ineptitude of the library profession in areas such as scientific management in general, and computer operations in 
particular. Consequently, the effort to rebuild the library at FAU was infused with a determination to change this image. In addition, every element of the new systems being planned was conscientiously studied in terms of its potential application on a state-wide basis.

For obvious reasons the Technical Services Division received the first priority in the reorganization effort. The goal was to have an entirely new system in full operation by the start of the new fiscal year on July 1, 1968-a system which would maximize the output of the division without recourse to tampering with the integrity of any of the records or bibliographic tools produced. ${ }^{4}$

There were two key elements in the new system. The most important was a public catalog split into its component parts, which made possible substantial reductions in labor costs through the elimination of all typing on catalog card sets except for original cataloging and in those instances where a change in the descriptive cataloging supplied by LC was necessary. This was achieved by the use of color highlighting to indicate titles, added entries, and subjects; by the extensive use of guide cards in all three parts of the catalog; and by not moving the LC number from the lower to the upper left hand corner of the card. $^{5}$ (See Figure 1.)

The second key element in the new system was a computer-assisted acquisitions program, the major functions of which were to (1) establish firm fiscal control over the book budget, utilizing practices acceptable to the controller and internal auditors of the university and the legislative auditors; (2) provide a wide range of essential management information impossible to obtain from a manual system; and (3) provide the academic departments with weekly status reports on faculty orders, allocate book funds, and print monthly lists of books accepted on the blanket approval plan arranged by LC class number. ${ }^{6}$
It would be difficult to exaggerate the importance of the new acquisitions information system. Its ultimate success established the library's credibility with respect to budgetary and fiscal matters with the Vice-President for Administrative Affairs which, in turn, made it possible to reestablish control over book purchasing and certain essential aspects of bill paying. In addition, the weekly status reports on book requests and allocated funds, and the classified list of books accepted on the blanket approval plan played an important role in earning the confidence of a critical and skeptical faculty. ${ }^{7}$

The target date of July 1, 1968, for having the whole new system in full operation was met. In the months that followed a program was developed to test its efficiency, i.e., optimal use of human and material resources; and its effectiveness, i.e., the level of achievement in terms of established program goals. The deus ex machina was a specially designed cost study which would provide a detailed analysis of average unit costs (per volume) in terms of both dollars and minutes per function performed by the type of employee-professional, subprofessional, clerical, and student assistants. $^{8}$

In the execution of the study the first step was an analysis of each position to determine the functions being performed. As these were identified they were merged into an index of functions covering the entire division. Since it was planned to utilize the computer for manipulating and analyzing the raw data, each function was assigned a unique four digit number within a general block of numbers assigned to each of the four departments in the division.

Next, a diary study was performed on each position to determine the time for functions performed. In calculating the average dollar cost per volume, the total amount of salary/wages paid was used. For the average cost in terms of 
Lee, Henry, 1926-

Handbook of epoxy resins , by, Henry Lee and $_{1}$ Kris Neville. New York, JicGraw-Hill (1967,

1 v. (varlous pagiags) Illus. $23 \mathrm{~cm}$. (McGraw-Hill handbooks) Includes bibllograptles.

1. Epoxy reslas. I. Neville, Kris, 1025- Jolat author. II. Title. IIL. Title: Epory resins. (SEnIEs) TP1180.E6LA

Lubrary of Coogress

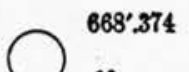
10,
Title (green)

Lee, Henry, 1926-

Handbook of epoxy resins by, Henry Lee and, Kris Neville. New York, McGraw.Hill, 1967,

$1 \mathrm{v}$. (varlous paglngs) Illus. $23 \mathrm{~cm}$. (3feGraw-HIII haddbooks) Includes blbllographles.

1. Epoxy resins. I. Neville, Kris, 1025-
II. Title. III. Title: Epoxy resins. (SERIEs)

Jolnt author.

$65-26165$

TP1180.E6LA

$668^{\prime} .374$

$65-26165$

Library of Congress

10,
Lee, Henry, 1926-

Handbook of epoxy resins, by, Henry Lee ,and, Kris Neville. New York, JfcGraw-Hill ‘1967,

1 v. (varlous paglags) Illus. $23 \mathrm{~cm}$. (JfCGraw-Hill bandbooks) Includes bibllographlea

1. Epoxy resins. I. Nerille, Kris, 1025- Jolat author. in. Title III, Title: Epoxp resing, (SERIES)

TP1180.E6LA

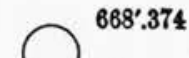

65-26165

Llbrary of Congress

10

\section{Added title (green)}

Lee, Henry, 1926-

Handbook of epoxy resins by, Henry Lee and, Kris

oville. New York, MfcGraw-Hill (1967,

7. (rarlous pagiags) Illus. $23 \mathrm{~cm}$ (3feGraw-Hill bandboots)

Inctudes blbllographles.

1. Epory resiok I Neville, Kris, 1025- Jolnt author.
II. Title. III. Titie: Epoxy neatin. (SERIEs)
TP1180.E6LA
Llbrary of Conzress


minutes, however, standardized times were used. This was done in order to base this part of the study on the number of minutes an employee was actually engaged in processing materials over a twelve-month period. In other words, hours not on the job for which employees were paid (specifically, vacations and coffee breaks) were deducted from the required work year. The standard times which resulted from this procedure were 1,800 hours per year for professionals and 1,875 hours for nonprofessionals. ${ }^{9}$ The wages of hourly workers were distributed by function on the basis of actual hours worked.

When the diary studies had been completed, the data for each position were entered on a data input coding sheet for transmittal to the key punch operator. Figure 2 shows how this information is entered and explains the various fields. Figure 3 shows a hypothetical work sheet of the kind generated for each type of position (professional, subprofessional, clerical, and student assistants) during the diary study.

Once the data from the individual position work sheets had been keypunched, all that was needed for the computer to produce the final report were the dates covered by the study and the number of volumes processed during this period. Figure 4 shows the summary results for the 1968/69 fiscal year during which 39,368 volumes were fully cataloged. Figures 5 and 6 show the distribution of costs by type of employee over the entire index of functions, and Figure 7 shows a detailed analysis of a single function (302, public catalog maintenance) by all types of employees. ${ }^{10}$

Although this initial attempt revealed the need for further refinements, the basic methodology proved sound and the results very useful. ${ }^{11}$ For instance, with respect to public catalog maintenance, it was discovered that this function involved portions of the time of eleven separate positions, and that it consumed
12.73 percent of the time and 10.82 percent of the total salaries/wages of the Technical Services Division. On the basis of this information, a separate catalog maintenance unit was created somewhat in advance of a prestudy prediction of when such a step would be necessary. The study also provided answers to such questions as what amount it cost to file the Title II depository card set by title; and what percent of the time spent on processing a volume is professional and what percent is nonprofessional (19.1 percent and 80.9 percent, respectively).

Since it had the potential to provide badly needed information regarding library operations at all seven universities in the Florida system, the study received considerable attention in the Board of Regents' office. In November, 1969, that body asked the author to spend a week each month in Tallahassee as a consultant to the Vice-Chancellor for Academic Affairs. The principal responsibilities of this assignment were to work with the other library directors in the system in implementing similar studies, and to work on a set of formulae for generating library budgets which would be realistic both in terms of the state's willingness and ability to provide budgetary support, and the responsibilities of the libraries in the system as derived from the programs of instruction and research on the individual campuses.

By the end of February, 1970, the unit cost studies had been completed at six of the seven libraries in the state university system. This project was greatly facilitated by Fred Jones, head of the Technical Services Division at Florida State University, who wrote the basic procedure manual.

In the meantime the original computer program developed at FAU was expanded to handle the input from all seven libraries, making possible a data bank, which could in due time become an integral part of the much larger information system being developed in 
COMPUTER TECHNOLOGY DEPT.

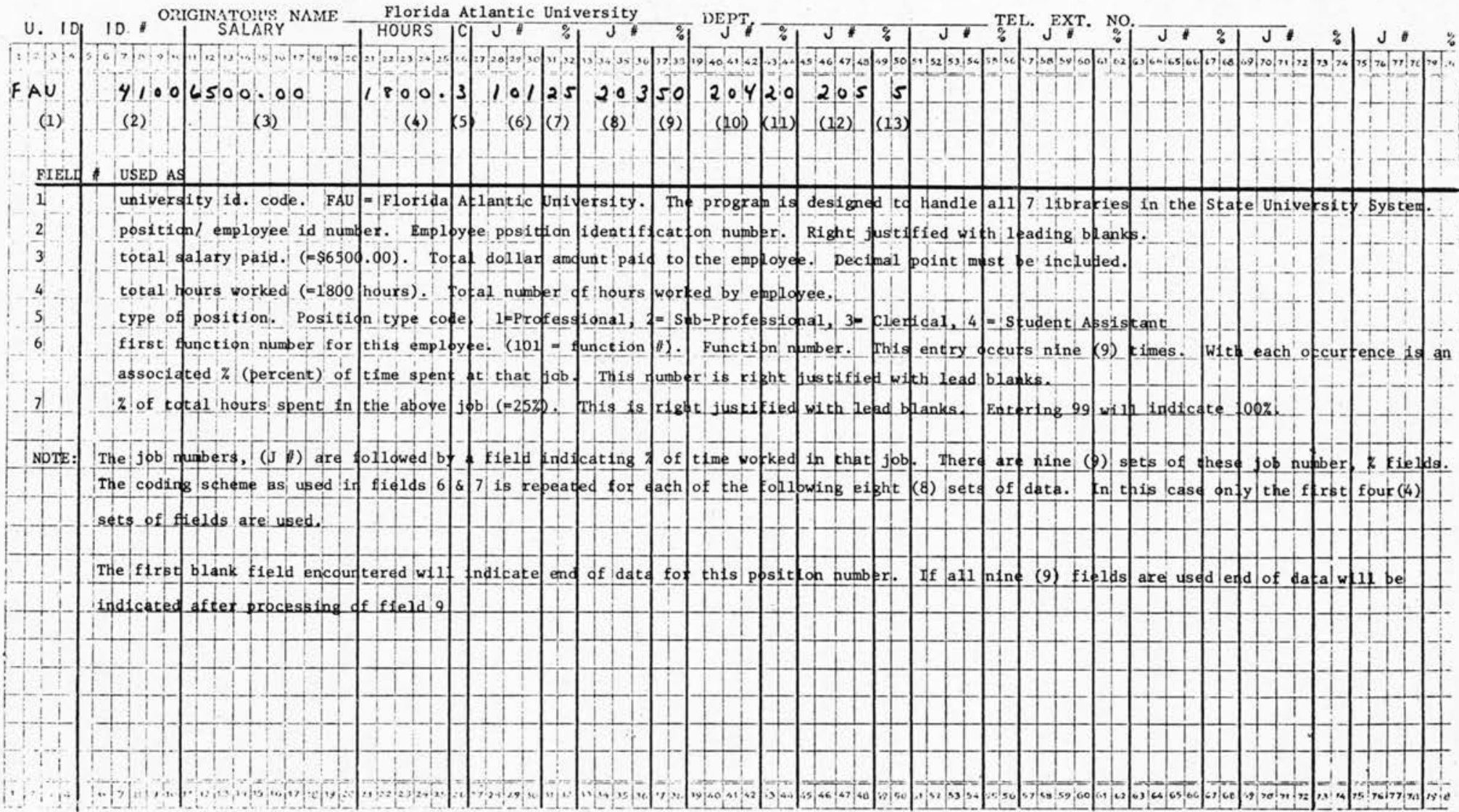




\begin{tabular}{|c|c|}
\hline Position 非 & $2120 \mathrm{P*}$ \\
\hline Function 非 & $\%$ of Time \\
\hline $\begin{array}{l}100 \\
200 \\
300\end{array}$ & $\begin{array}{l}30 \\
35 \\
35\end{array}$ \\
\hline Annual Salary & $\$ 8,600$ \\
\hline *Professional & \\
\hline
\end{tabular}

\begin{tabular}{|c|c|c|}
\hline Position 非 & $4162 \mathrm{sP} *$ & Name \\
\hline Function 非 & $\%$ of Time & \\
\hline $\begin{array}{l}200 \\
300 \\
500\end{array}$ & $\begin{array}{l}65 \\
25 \\
10\end{array}$ & \\
\hline \multicolumn{3}{|c|}{ Annual Salary } \\
\hline *Sub-Profes & nal & \\
\hline
\end{tabular}

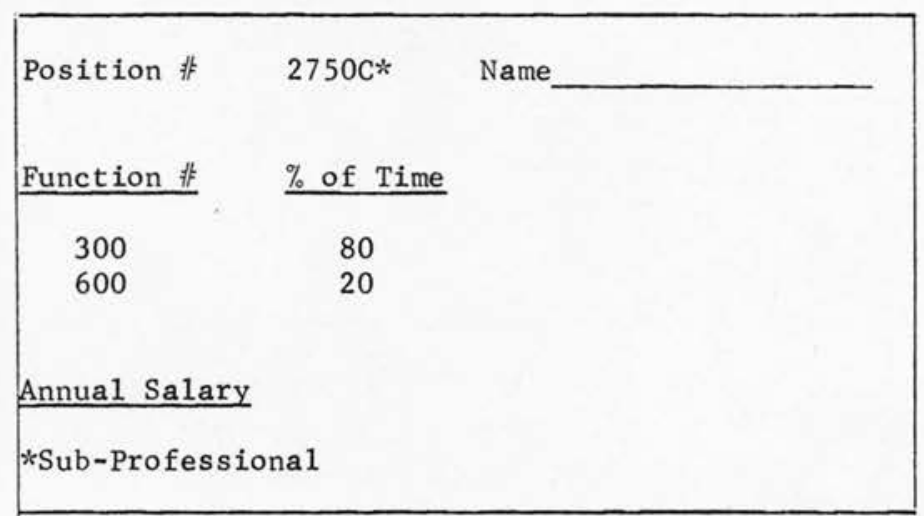

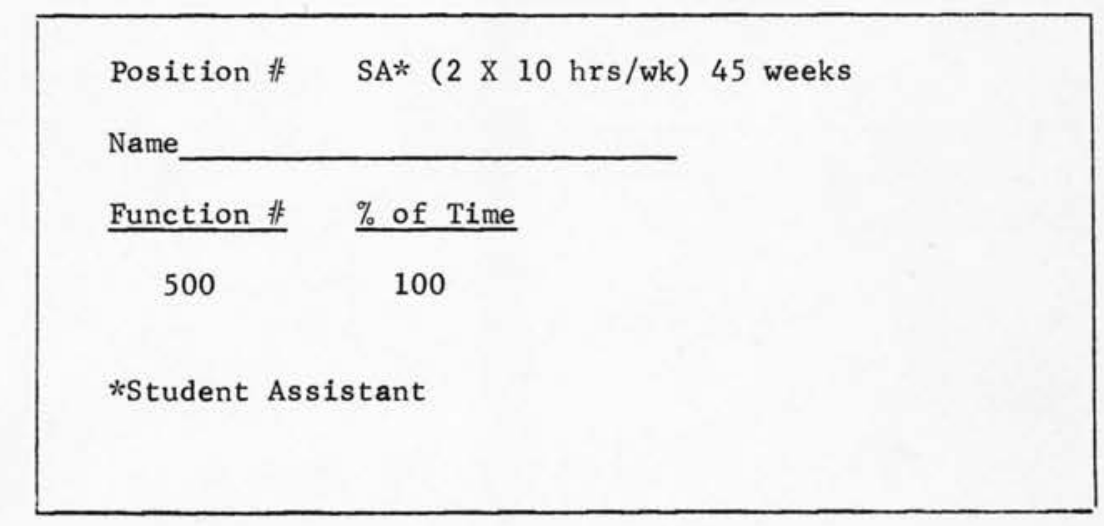


ANALYSIS COVERS PERIOD FROM OT/O1/OA TO OO/SO/BY

NUMBER OF VOLUMES PHOCESSED $=3936 \mathrm{H}$

TOTAL HUURS $=4$ HOHS.1S

TOTAL SALARY $=12058$. HB

COST/VOLUME $=3.06$

MINUTESTVILUME $=\quad 74.20$

ANALYSIS CUVERS PEHTOD FROM OT/01/O8 TII 00/30/6?

SUMMARY BY JOH CODE

ALL POSITIONS

joa no.

JOB TITLE

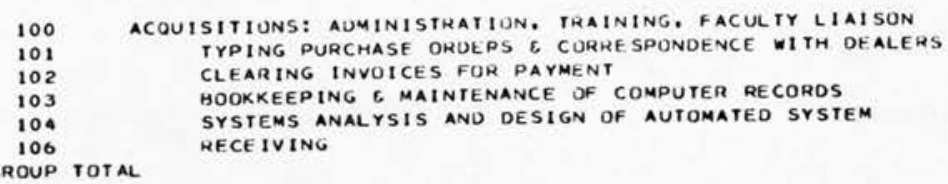

GROUP TOTAL
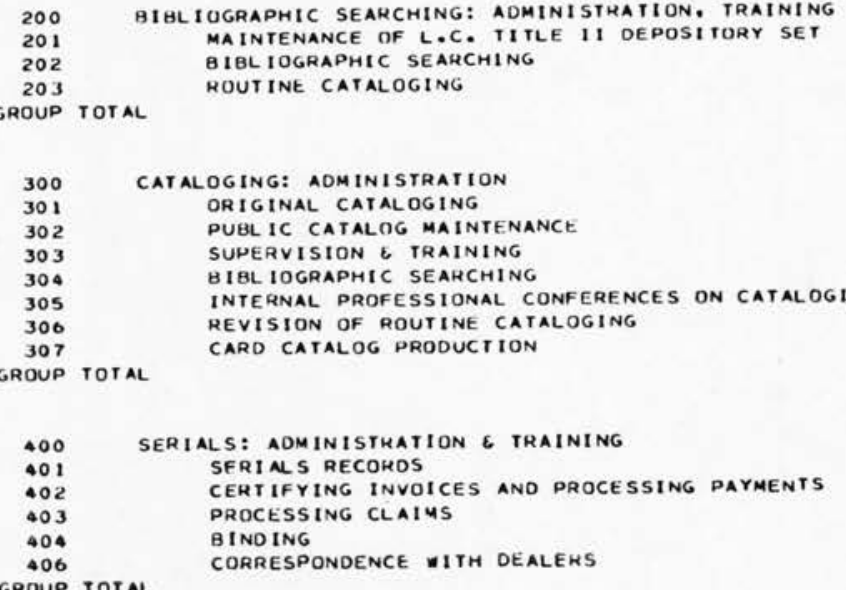

Totacs
TOTAL SAL

\begin{tabular}{|c|c|c|c|}
\hline SALARY & TOTAL HOURS & S/VOLUME & MIN./VOLUME \\
\hline 9287.40 & 1944.00 & 0.24 & 2.96 \\
\hline 820.56 & 1587.50 & 0.02 & 2.57 \\
\hline 3270.05 & 2625.00 & 0.08 & 4.00 \\
\hline 5502.80 & 2625.00 & 0.14 & 4.00 \\
\hline 752.40 & 180.00 & 0.02 & 0.27 \\
\hline $1768.0 \mathrm{H}$ & 937.50 & 0.04 & 1.43 \\
\hline 21401.27 & 9999.00 & 0.54 & 15.24 \\
\hline 2268.00 & 360.00 & 0.06 & 0.55 \\
\hline 2268.33 & 1371.50 & 0.06 & 2.09 \\
\hline 7100.00 & 3056.25 & 0.18 & 4.66 \\
\hline 9974.24 & 3975.00 & 0.25 & 6.00 \\
\hline 21616.57 & 8762.75 & 0.55 & 13.36 \\
\hline 8166.56 & 1713.60 & 0.21 & 2.61 \\
\hline (1) & 2106.00 & 0.21 & \\
\hline
\end{tabular}

13042.8

5036.40

2186.55

2001.10

6558.9

51518.32

10548.79

6948.35

3477.60
750.00

3958.70

369.45

2100.00

0198.35
1443.78

1443.78
534.56

538.5

3639.50

1944.00

4163.25

1687.50

468.75

502.50

5150

0.21

0.33

0.13

0.06

0.05

0.17

1.31

9.45

2.20

0.82

0.75
5.00

5.00
5.55
29.58

0.27

0.18

0.09

0.02

0.10

06

2.96

6.35

2.57

0.71

3.14
0.29

16.02

120589.63

40685.16

3.06

74.20 


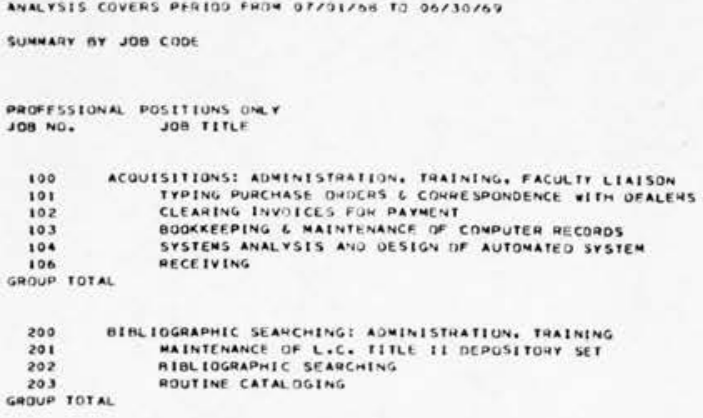

rorals

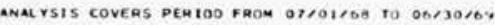

SUMmarr or Jos coof
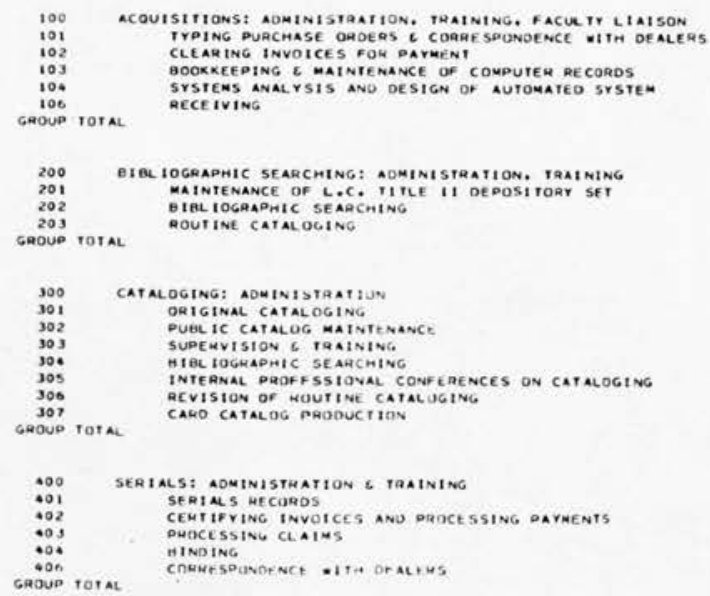

$\begin{array}{ccll}0.0 & 0.0 & 0.0 & 0.0 \\ 2445.93 & 720.00 & 0.00 & 1.10 \\ 917.22 & 270.00 & 0.02 & 0.01 \\ 1039.52 & 306.00 & 0.03 & 0.07 \\ 550.33 & 162.00 & 0.01 & 0.25 \\ 128.04 & 126.00 & 0.01 & 0.19 \\ 0.0 & 0.00 & 0.0 & 0.00 \\ 0.0 & 0.0 & 0.0 & 0.0 \\ 5381.03 & 1584.00 & 0.14 & 2.41\end{array}$


CLERICAL POSITIONS OMar
JOB NO. JOH TILE

ACOUISITHONS: AUMINISTRATION. TRABNING. FACULTY LAASON

101 TrPING PURCHASE UMDERS G CDARE

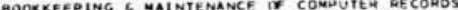
SYSTENS ANALYSIS AND DESIG DF AUTOMATEO SYSTE* aECEIVING

Goup ratal

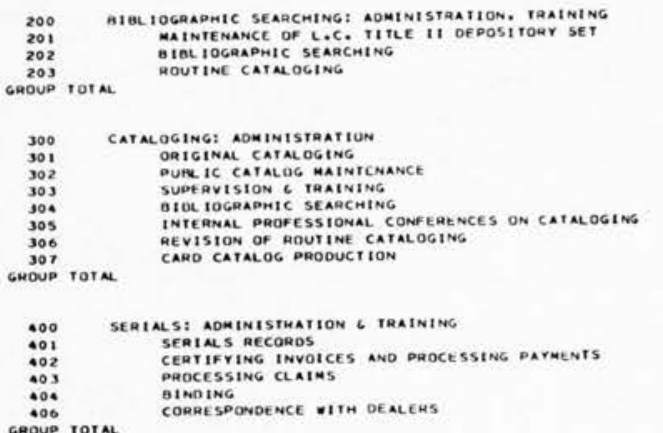

rotals

amin

SUMuarer ay Joe cooe

STUDENT ASSISTANT POSITIONS ONAT

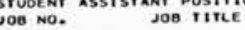
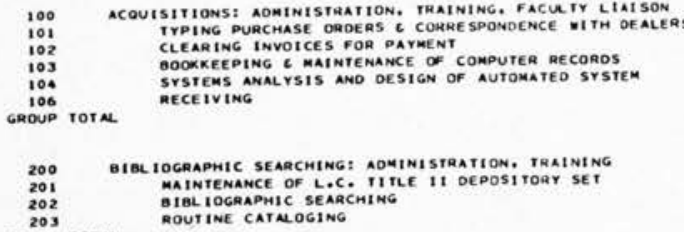

202 BIBL IOGAAPHIC SEARCHING
203
ROUTINE CATNOGING

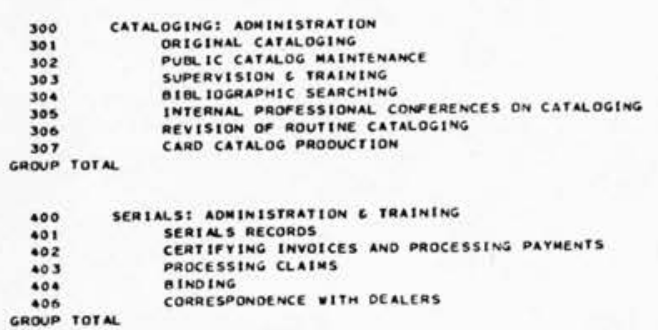

rotals

\begin{tabular}{|c|c|c|c|}
\hline TOTAL SALARY & TOTAL mouks & strolume & NIN./va vefe \\
\hline 0.0 & 0.0 & 0.0 & 0.0 \\
\hline 020.56 & 1687.50 & 0.02 & 2.57 \\
\hline 3270.05 & $\begin{array}{l}2625.00 \\
2625.00\end{array}$ & $0.0 a$ & $\because \because 0$ \\
\hline $\begin{array}{c}5502.80 \\
0.0\end{array}$ & $\begin{array}{c}2625.00 \\
0.0\end{array}$ & 0.14 & $\because 00$ \\
\hline $\begin{array}{c}0.0 \\
1708.00\end{array}$ & 937.50 & 0.0 & 0.0 \\
\hline $\begin{array}{l}1708.00 \\
11301,44\end{array}$ & 7875.00 & 0.29 & 12.00 \\
\hline 0.0 & 0.0 & 0.0 & 0.0 \\
\hline 1842.33 & 1087.50 & 0.05 & 1.60 \\
\hline 7100.00 & 3056.25 & 0.18 & 006 \\
\hline 9974.24 & 3975.00 & 0.25 & 6.06 \\
\hline 18922.57 & 0118.75 & 0.40 & 12.31 \\
\hline 0.0 & 0.0 & 0.0 & 0.0 \\
\hline 0.0 & 0.0 & 0.0 & 0.0 \\
\hline 9235.63 & 0968.75 & 0.23 & 7.57 \\
\hline $\begin{array}{c}1490.00 \\
0.0\end{array}$ & 502.50 & 0.04 & 0.06 \\
\hline $\begin{array}{l}0.0 \\
0.0\end{array}$ & 0.0 & 0.0 & 0.0 \\
\hline 0558.97 & 0.0 & 0.0 & 0.0 \\
\hline $\begin{array}{l}6558.97 \\
5453.02\end{array}$ & $\begin{array}{l}3281.25 \\
3107.50\end{array}$ & 0.17 & 5.00 \\
\hline $\begin{array}{r}5453.02 \\
22737.62\end{array}$ & $\begin{array}{r}3107.500 \\
12000.00\end{array}$ & 0.58 & 10.26 \\
\hline & & & \\
\hline 0.000 .35 & 2531.25 & 0.011 & 0.0 \\
\hline $\begin{array}{l}5000.35 \\
3077.60\end{array}$ & 1687.50 & 0.09 & 2.57 \\
\hline 750.00 & 460.75 & 0.02 & 0.71 \\
\hline 3958.70 & 2002.50 & 0.10 & 3.14 \\
\hline 369.45 & 187.50 & 0.01 & $\begin{array}{r}0.29 \\
10.57\end{array}$ \\
\hline 13050.09 & 0037.50 & 0.33 & 10.57 \\
\hline 66077.75 & 34931.25 & 1.68 & 53.24 \\
\hline
\end{tabular}

TOTAL SML ART

TOTAL MOURS

s/vOL UME

min./ volume

0.0
0.0
0.0
0.0
0.0
0.0

0.0
0.0
0.0
0.0
0.0
0.0
0.0

$\begin{array}{ll}0.0 & 0.0 \\ 0.0 & 0.0 \\ 0.0 & 0.0 \\ 0.0 & 0.0 \\ 0.0 & 0.0 \\ 0.0 & 0.0 \\ 0.0 & 0.0\end{array}$

0.0
20.00

120.00
0.0
0.0

284.000

284.00
0.0

$0.0 \quad 0.0$

$\begin{array}{ll}0.01 & 0.0 \\ 0.0 & 0.0 \\ 0.01 & 0.03\end{array}$

0.0

284.00

$0.0 \quad 0.0$

0.0
0.0
$052=00$
0.0
0.0
0.0
0.0

.52 .00

0.0
0.02
0.0
0.0
0.0
0.0

678.0

0.0

678.00

904.00

$24+8.00$

1632.00

0.0
0.0
0.0

0.0
0.0
0.0

1632.00

$\begin{array}{ll}0.0 & 0.0 \\ 0.06 & 2.40 \\ 0.0 & 0.0 \\ 0.0 & 0.0 \\ 0.0 & 0.0 \\ 0.0 & 0.0 \\ 0.06 & 2.08\end{array}$

.230 .00
0.0
0.0
0.0
0.0
0.0
0.0
0.0
0.43
0.00
0.0
0.09
0.0
0.0
0.09
0.0
0.0
0.0
0.0
0.60
1.30
0.0
2.09
0.0
0.0
0.0
0.0
2009
1030
100

Figure 6 
the Board of Regents' office to undergird the total planning effort of the university system.

Since the unit cost studies had the potential of providing a model for budgeting technical services positions, work on the formulae for generating library budgets was confined to the problems of size of library and public services positions. Considerable work has already been done on formulae for the size of libraries. As an initial step, it was decided to test the relevance of two of the best known for the Florida university system -that developed by Verner W. Clapp and Robert T. Jordan, and the formula adopted by the Interinstitutional Committee of Business Officers of the State of Washington University System. ${ }^{12}$

Both proved to have serious liabilities. In the first place, each rated the libraries of the two largest institutions at approximately 50 percent of adequacy. While it is probable that these institutions have overextended their instructional and research programs in terms of what they have been willing to allocate for library resources, to propose a formula which would require doubling the size of these libraries just to support present programs would have been politically naive no matter what its merits. In addition, both formulae worked against the interests of the newer institutions in the system, all of which are rapidly expanding and attempting to implement as quickly as possible broad scale graduate programs at both the master and the doctoral level. ${ }^{13}$

In the end, the Clapp-Jordan formula was rejected in favor of modifying the input factors of the Washington formula. Two modifications were made on that part related to size of library: (1) the volume allocation for M.A. programs with doctorates was dropped; and (2) the volume allocation for doctoral level programs was decreased. ${ }^{14}$

The reasons for these modifications were as follows. First, the allocations for M.A. programs with doctorates seemed redundant as the terminal degree ought logically to provide an adequate level of support for all lower level degrees. Second, since M.A. programs tend to breed doctorates, raising the volume allocation for such programs without doctorates would have two distinct advantages; it would tend to build library resources in advance of the inevitable doctorate, and it would more adequately meet the needs of the newer university libraries trying to support a proliferation of programs at the M.A. level. Finally, the reduction of the volume allocation for doctoral programs was partially related to the increase at the M.A. level, and partly arbitrary. Figure 8 shows the input factors for the formula adopted by the state of Washington, and also, as modified. Figure 9 shows the results of applying all three formulae to the libraries of the Florida university system.

The modified Washington formula placed the volume deficiency of the two largest libraries at approximately 33 percent, or about 500,000 volumes each. Although still substantial, the gap between the scope of their academic programs and adequate library resources was reduced to a point where real progress toward closing it might be built into the state university system's first programmed budget which would project programs and budgets through 1976. Finally, the modifications produced results which seemed to serve better the needs of the newer institutions in the system.

Applying the Washington formulae for generating library positions produced a startling and provocative result-a doubling of the number of library positions recommended by the Board of Regents for the university system for 1969/70. Although the university libraries in Florida share the common problem of insufficient staffing, neither the system as a whole nor any single library is forced to operate with half 
The State of Washington

and Modified State of Washington Formulae FOR SIZE OF LIBRARY ${ }^{\circ}$

\begin{tabular}{lcc}
\hline \hline & $\begin{array}{c}\text { State of } \\
\text { Washington Formula }\end{array}$ & $\begin{array}{c}\text { Modified State of } \\
\text { Washington Formula }\end{array}$ \\
\hline Basic Collection & 85,000 & 85,000 \\
Per FTE Faculty & 100 & 100 \\
Per FTE Student & 15 & 15 \\
Per M.A. Field, no doctorate & 6,100 & 7,500 \\
Per M.A. Field, with doctorate & 3,050 & 15,000 \\
Per Doctorate & 24,500 & \\
\hline
\end{tabular}

Formula for Estimating the Stze for Minimal Adequacy of tHe Collections of Senior College and UNIVERSITY Libraries

\begin{tabular}{|c|c|c|c|c|c|c|}
\hline & \multicolumn{2}{|c|}{ Books } & \multicolumn{2}{|c|}{ Periodicals } & \multirow{2}{*}{$\begin{array}{l}\text { Documents } \\
\text { Volumes }\end{array}$} & \multirow{2}{*}{$\begin{array}{l}\text { Total } \\
\text { Volumes }\end{array}$} \\
\hline & Titles & Volumes & Titles & Volumes & & \\
\hline Basic collection & 35,000 & 42,000 & 250 & 3,750 & 5,000 & 50,750 \\
\hline Faculty (FTE) & & 60 & 1 & 15 & 25 & 100 \\
\hline Student (FTE) & & 10 & & 1 & 1 & 12 \\
\hline \multicolumn{7}{|l|}{$\begin{array}{l}\text { Undergraduate in honors } \\
\text { or independent study } \\
\text { programs }\end{array}$} \\
\hline & 10 & 12 & & & & 12 \\
\hline $\begin{array}{l}\text { Undergraduate major } \\
\text { subject field }\end{array}$ & 200 & 240 & 3 & 45 & 50 & 335 \\
\hline Per M.A. field & 2,000 & 2,400 & 10 & 150 & 500 & 3,050 \\
\hline Per Ph.D. field & 15,000 & 18,000 & 100 & 1,500 & 5,000 & 24,500 \\
\hline
\end{tabular}

- A minimum number of acquisitions to 5 percent of the total volume count at the start of each fiscal year is provided for those institutions which reach or exceed 100 percent of formula.

Figure 8

the number of staff it needs. These results raised serious questions as to the credibility of the Washington formula, and led to the conclusion that as in the case of the formula for size of library, certain modifications were necessary.

The factors used to compute weighted users were adjusted to conform to those in the formula for generating FTE faculty positions at the various levels at the University of Florida. ${ }^{15}$ This was done out of the belief that it would be difficult to argue that the library responsibilities relative to the needs of a beginning graduate student, for example, were heavier than those of the professor. The second change dealt with the factor for dividing total weighted enrollment to produce the number of public services positions. It was arbitrarily reduced from 220 to 300 .
The formula as adjusted produced 56.6 new public services positions for the system, a figure which appeared to be reasonable in terms of possible funding and the actual needs of the libraries. Figure 10 shows the Washington formulae for both technical and public services positions and the latter as modified.

Neither of these formulae were officially approved by the Interinstitutional Committee of Librarians. But as Spinoza noted, "nature abhors a vacuum." As the deadline approached for submitting the first program budget projecting needs through 1976/77, guidelines for computing library budgets arrived from Tallahassee. Included were the modified Washington formulae for size of library and public services positions. Until such time as further work had been done on 


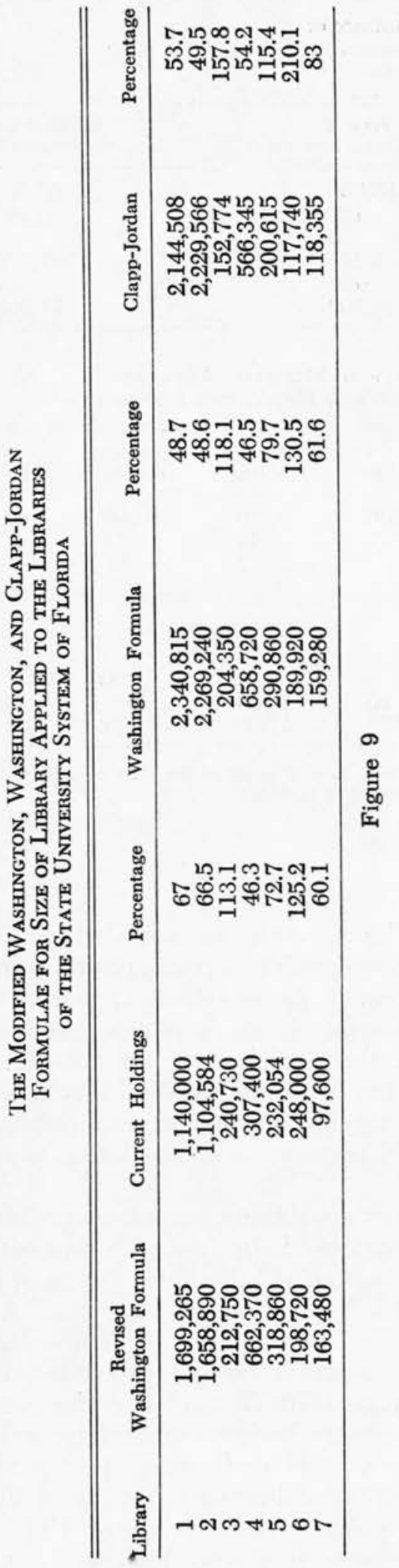

the unit cost studies, the old formula of one F.T.E. technical services position for each 1,000 volumes cataloged was to remain in effect.

The significance of this development will not be lost on anyone who has wrestled with a program budget or watched in angry despair the continuing expansion of instructional and research programs without proportional increases in library resources. In the first place, with the approval of the basic budget generating formulae, the preparation of the library's programmed budget was immensely simplified and rationalized. Once the program projections of the academic deans were available it was a matter of applying the basic formulae plus a number of additional input factors, such as projections for the cost of library materials, wage and salary increases, and adjustments in total book budget related to free or gift materials. ${ }^{16}$ Again, the situation was ideally adapted to the unique capabilities of the computer.

With the approval of the Board of Regents' office, the FAU library ran an experimental budget for 1971/72 utilizing all of the above mentioned input data which provided figures for 60 to 100 percent of formula at 5 percent stages.

In addition, the program also allocated the entire library budget back to the individual academic departments whose program planning had generated it. Thus, for example, it was possible to determine the total library support dollars needed for a single lower division, upper division, or M.A. level course in History. Although the program was far from perfect, it was instrumental in producing additional guidelines for the university libraries for the preparation of the legislative budget request which called for funding at 75 percent of formula in $1971 / 72$ and a goal of 100 percent funding by $1976 / 77$ to be reached in 5 percent stages. ${ }^{17}$ 
Washington Personnel Generating formulae

Public Services

100/200 level FTE students @ 1

$300 / 400$ level FTE students @ 1.80

500 level FTE students @ 4.30

600 level FTE students@6.00

Registered Outside Borrower @ 1.00

Weighted User Factor 220
(1)

$(300)$

\section{Technical Services}

(1) Add number of units of library resources to be added in the year in which the calculation applies to the total held at the beginning of that year.

(2) Multiply this figure by the units to be added and divide by $1,000,000$ to derive weighted units to be added.

(3) Multiply the weighted units to be added by the following factors and add the following constants.

1 to 14,999 WUA $\times .01514+67$

15,000 to 41,999 WUA $\times .00664+194$

42,000 to 300,000 WUA $\times .00360+322$

(4) Divide weighted units to be added by the factor resulting from the above calculations to derive FTE Technical Services staff.

- Modifications.

Figure 10

Perhaps the significance of the FAU unit cost studies and the budgeting formulae lies in the fact that they represented to a large degree a response to demands emanating from agencies at the state level, not from the university librarians. In this respect, Florida is not unique. Across the country an increasing number of state legislatures are demanding more and more information by which to evaluate the current budget requests of state agencies and to project the budgetary needs of the future. Massive data banks are being created into which are being fed performance data on governmental agencies at all levels. In the sancta sanctorum of the academy, hitherto unmentionable subjects, such as performance measurement for faculty, are being openly espoused and studied by legislators and planning groups outside the university. Here and there the costs of operating the university library are beginning to come under close scrutiny.

With evidence of a leveling off of funding for higher education despite increased enrollments, the pressure to account for each available dollar through some kind of performance measurement will undoubtedly increase. The degree to which the academic librarians are willing to move in this direction will to some extent determine the status of the profession in the immediate future. The people whose responsibility it is to provide the money are beginning to demand facts, not "self-evident truths." It would appear that the academic librarian must choose between being dragged along by the course of events or accepting an opportunity and a challenge for professional accomplishment and development of truly great proportions. What is now being asked of us by outside agencies is, in reality, only what we should be asking ourselves.

Anyone who has ever been through the agony of preparing a program budget can hardly view the yearly budget preparation process with anything but despair. Yet because the library cannot 
even begin its task until the academic planners have agreed upon programs, our task within this type of budgetary procedure is considerably easier than that of an academic department head. A future in which program budgeting is a permanent fixture may not be a pleasant prospect, but it seems inevitable, and every academic administrator ought to be preparing himself for the fateful day of its arrival.

As for academic libraries, at the very least, we ought to be working toward a far broader application of the unit cost study approach to technical service op- erations. Utilized across the country, such studies, even without a generally accepted dictionary of standard functions, would reveal a wealth of information regarding the profession's pragmatic response to the acquisitions and processing problems generated by the tremendous increase in book budgets over the past two decades. Questions would be raised which would require answers, and in seeking them, the profession could make great strides in the direction of scientific management of the human and material resources with which we are entrusted.

\section{References}

1. No attempt will be made to try and explain why the original program failed. The fact of the failure, however, cannot be ignored. Perhaps a clue can be found in Robert Townsend's rule regarding "Computers and Their Priest." "No matter what the experts say, never automate a manual function without a long enough period of dual operation." "Up the Organization." Harper's, March 1970, p.75. A bibliography can be found at the end of this article for those interested in the literature on the FAU library.

2. Nowhere in the report were university librarians dealt with as a group. CMP's conclusions revealed themselves only in their recommended classification scale in which the librarians were conspicuous by their absence from the A\&P group.

3. The new salary and classification plan embodied three ranks, assistant librarian $(\$ 8,150-12,100)$, associate librarian $(\$ 9,600-14,500)$, and librarian $(\$ 11,650-17,600)$. The hard line taken in the Board of Regents' office regarding its implication was evident in its guidelines for preparing the 1970/71 budget. These permitted hiring at the new salary levels, but specifically rejected establishing a new base which would automatically upgrade the salaries of all professional positions. Clearly, implementation was to be on a piecemeal basis with each request judged on its individual merits.

4. At no time was any consideration given to speed cataloging or brief listing as a means of eliminating or preventing backlogs of unprocessed materials.

5. Figure 1 shows part of a sample set of cards ready for filing. Although developed independently, the basic system at FAU is almost identical in its major features to that implemented at the University of Wisconsin-Milwaukee by Mark Gormley and Peter SpyersDuran, and later, by Spyers-Duran at Western Michigan University, Kalamazoo. Studies at FAU showed a 71 percent savings in card preparation. At WMU, the savings in filing time in a three-way split catalog amounted to 50 percent.

6. For a description of the system see International Business Machines, Library Applications on the System/360 at Florida Atlantic University, January 1, 1970 (GK20-0362-0).

7. In August, 1970, this program and the FAU computer-based circulation program were adopted as standard 
systems for the nine university libraries in the state university system of Florida.

8. The difference between this approach and a true time and motion study is that the latter attempts to determine a standard rather than average cost per work unit performed. Standard costs assume 100 percent efficiency and are always lower than average costs. In the case where only the cost of labor per work unit is being calculated, the difference between the average cost per volume and the standard cost per volume would be largely accounted for by inefficient supervision.

9. No attempt was made to deduct sick leave for which the employee was paid. Consequently, the times in terms of minutes per function were slightly higher than they would have been if this had been done.

10. A copy of the manual for the unit cost study and the FORTRAN program for manipulating the raw data on the computer can be obtained by writing to the author.

11. The single most important improvement needed was a greatly expanded index of functions. For the 1969/70 fiscal year the standard list of technical services functions established by Richard M. Dougherty, Lawrence Leonard, and Joan Maier was used. See their book Centralized Book Processing (Scarecrow Press, 1969), 60-62. In addition, original cataloging was broken down by language.

12. Verner W. Clapp and Robert T. Jordan, "Quantitative Criteria for Adequacy of Academic Library Collections," College \& Research Libraries 26:371-80 (September 1965), State University System of Washington. Office of Interinstitutional Business Studies. A Model Budget Analysis System For Program 05, Libraries, October, 1968. (Copies can be obtained from Denis J. Curry, Director, 1020 E. 5th Ave., Olympia, Washington 98501.)

13. Because the state legislature was extremely sensitive to the high costs of graduate programs, and had in fact established fairly stringent guidelines for growth in this area, any formula approach to budgeting for library resources based on program level was inherently dangerous to the ambitions of the newer institutions. The two older institutions could argue that the major effort should be to bring the library resources for existing graduate programs up to adequacy before new programs were approved elsewhere in the state. Thus, it is almost inevitable that any system-wide approach to library budgeting becomes immediately involved in the political struggle of the "haves" and the "have nots" for the limited resources available, and budgetary realities are lost in a welter of parochial interests. The basic problem of constructing a formula for size of library for the Florida university system was to find a course aimed at program quality between the Scylla of politically impossible budget requests and the Charybdis of a product which would further aggravate the competition between seven existing and two incipient institutions for the limited tax dollar. Jordan and Clapp were (quite rightly) not concerned with this problem. The state of Washington, on the other hand, was. They were fortunate, however, in that library support over the years had come far closer to keeping pace with academic program expansion than was the case in Florida. Consequently, a formula which was realistic in that state was not realistic when applied to the Florida university system.

14. See Figure 9 for the results of applying the Clapp-Jordan, the state of Washington, and the modified state of Washington formulae to the Florida university system. Enrollment and program figures used for the universities in the Florida system were those recommended by the State Board of Regents for $1969 / 70$.

15. Lower division 1:400; upper division $1: 255$; 500 level 1:195; and 600 level $1: 85$. Translated into weighting factors the ratios would be $1.0,1.76,2.05$, and 4.76. 
16. The size of library formulae produces the total number of volumes needed each year. From this must be subtracted the number of volumes anticipated which will be acquired at no cost, leaving the number to be purchased. This figure multiplied by the projected per volume cost produces the book budget.

17. As already noted, the modified Washington formula was adopted by the State Board of Regents for computing the 1971/72 budget requests of the university libraries. At least two of the newer institutions reached or exceeded minimum standards as determined by the formula, and were, therefore, limited to a growth increment in 1971/ 72 of 5 percent of the total volumes projected as of June 30,1971 . The reaction on these campuses was predictable. An adjustment, however, was worked out with the Board of Regents' office by which the amount spent for continuations in 1970/71 would be added to the dollar figure produced by a 5 percent increase in volumes for 1971/ 72.

\section{ARTICles ON THE Library at \\ Florida AtLaNTIC UNIVERSITY}

1. Becker, J. "Using Computers in a New University Library," ALA Bulletin 59: 823-26 (October 1965).

2. Cordell, H. W. "Library Public Services in the Age of Data-Processing," Florida Libraries 15:11-14 (June 1964).

3. Dahlberg, I. "Verivicklung einer Modernen Universitatsbibliothek" (Automation of Library Processes), Verband der Bibliotheken des Landes NordrheinWestfalen. Mitteilungsblatt. 15:86-105 (15 July 1965).

4. Heiliger, E. M. "Staffing a Computer Based Library," Library Journal 89: 2738-39 (July 1964).

5. Heiliger, E. M. "Use of a Computer at Florida Atlantic University Library for
Mechanized Catalog Production" (In Library Mechanization Symposium, May 25-27, 1964. International Business Machine, nd, p. 165-86).

6. Heiliger, E. M., J. M. Perreault, and C. D. Highum. "Florida Atlantic University," College \& Research Libraries 25:181-99 (May 1964).

7. Perreault, J. M. "Computerized Cataloging: The Computerized Catalog at FAU," Library Resources \& Technical Services 9:20-34 (Winter 1965).

8. Srygley, T. F. "Serials Record Instructions for a Computerized Serial System," Library Resources \& Technical Services 8:248-56 (Summer 1964). 